\title{
Critical Analysis of Social Genetics and Linguistic Inquiry
}

\author{
Samuel Leykun \\ Department of Linguistics, Ambo University, Ambo, Ethiopia \\ Email address: \\ slekun.leykun455@gmail.com

\section{To cite this article:} \\ Samuel Leykun. Critical Analysis of Social Genetics and Linguistic Inquiry. International Journal of Language and Linguistics. \\ Vol. 8, No. 1, 2020, pp. 11-16. doi: 10.11648/j.ij11.20200801.12
}

Received: August 27, 2019; Accepted: October 24, 2019; Published: January 7, 2020

\begin{abstract}
Human being on Earth has undergone several transitions during its history, from the fire age to modern technology. There has been notable progress in linguistic development and social development. Sociolinguistics and Social genetics as a newlly emerging discipline have strong relationship and enaged with one another. This study tried to analyzed critically the social genetics and linguistic inquiry of human being regardless of anything. The objectives of the study were to introduce this complex idea to the biologists and linguists to reduce their racial baises and to make sense of social genetics and sociolinguistics are the major parameter of human race and genetics than hereditary genetics. The critical paradigm is used as paradigm of the study. Regarding techniques of data analysis, the qualitative approach is utilized in this study. Concerning data collection tools, the secondary data were collected from journals, findings of different researches, books, and proceedings. Therefore, this research is a desktop research. To mention some of the findings, the concept of hereditary genetics distinguish an individual or a group of individual from the other is a refutational way that triggers a misconception, and incorrect. The world outlook, and paradigm of the target speech community or an individual is not a consequence of hereditary genetics, rather this can be considered as a misconception of genetics. $99.9 \%$ of the DNA of two human is identical. But also, more than $99 \%$ of language of the world share same consonants and vowels. The phoneme chart of most language of the world is almost the same. Therefore, ethnic conflict in different part of the world particularly Africa, Areb countires, and Asia has no theoretical and practical background. More explicitly, ethnic conflict among two races has no reason and a conflict between groups are those share $99.9 \%$ of the DNA and $99 \%$ of the linguitic characteristics.
\end{abstract}

Keywords: Social Genetics, Sociolinguistics, Proto-language, Proto-world Language

\section{Introduction}

\subsection{Background of the Study}

The concept of genetics has been described from different perspectives by scholars. These scholars try to present genome from both hard science and soft science in general. More explicitly, the concept is presented from biology, and sociology perspectives. This study attempted to assess the concept of social genetics from linguistics perspectives. Linguitics as a sub-field of humanities and interdisciplinary subject can be considered as an social genetics.

In this study the researcher was interested in identifying the role of sociolinguistics in social genetics on the one hand and geners of genetic science as a social genetics on the other hand.

In sociolinguistics the concepts language and related components of humaniterian entity such as culture, value, norms, assets, philosophy, wisdom, are acquired from the environment. This notion predominantly introduced in linguistics. Currently in the development of social genomics bringing together humanities, social science and genetic research in general and sociolingiustics, sociology and biology in particular.

Numerous research finding depict that, the science of genetics has been used to justify policies that helped one race by harming another [10]. Even today the belief that races are genetically dissimilar is used to justify interethnic hostility [12], prejudice [3], segregative behavior [23], and discriminatory policies [22].

Research suggests that, the relationship between perceptions of human genetic variation and stereotype endorsement is mediated by genetic essentialism [3, 4]. Genetic ssentialism of race is a social cognitive bias which assumes that the genes inherent in people make same race individuals physically and behaviorally uniformand people of 
different races physically and behaviorally discrete [1].

Over the last 300 years the oppression and subjugation of various ethnic groups around the world has been rationalized through the idea that inequality is a natural product of human biological difference $[6,9,5,18]$. Particularly in Europe and in those continents colonized by Europeans, science education has also been used to lend false credence to the belief that Western Europeans are biologically superior to other groups [18, 24]. Unfortunately, this belief is still apparent in education today as a sociolinguistics field of proto language family and genetic relatednes between the native speakers of the languages under the same language phylum. In this regard there are different assumptions. The first is the premise that people of the native speaker of same language family are genetically uniform. Such argument may resulted to anachronistic in globalization era.

Studies shows that, uniformity and discreteness beliefs about race are biologically flawed, it should come as no surprise that there has never been any agreement within the biological or anthropological sciences about whether human races are biologically real $[8,18]$. Even today there is no scientific consensus that race is biologically real $[6,8,13$, 14]. Because, the source of human being is East African Ethiopia. The same source which is very hard to depart one from the other based on language or history.

When people are led to believe that scientists can distinguish one group from another based on traits that are similar within a group and different between groups, they are more likely to search for an underlying essence to differentiate ingroups from outgroups. Increased belief in an inherent essence then leads individuals to evaluate ingroups more favorably than outgroups [26] and to categorize people into more discrete racial groups [2].

According to, J. Schnittker \& J. Behrman (unpublished manuscript) quoted in [10] raise the possibility that estimates of the strong positive effect of schooling on social connectedness may be confounded by unobserved characteristics that cause differences in educational attainment. They find greatly diminished and even sometimes negative effects when attention is restricted to monozygotic (MZ, identical) twins. Because MZ twins share not only genetic endowments but also genericfeatures of family background and cohort, the strategy of estimating effects by comparing $\mathrm{MZ}$ twins eliminates a wide variety of potential confounders. Even so, MZ twins do not differ in educational attainment randomly, and estimates following this strategy may still be confounded by psychological and other characteristics that are not fully determined by genes and shared family environment. In other words, if one believes that cognitive ability confounds an estimated effect of educational attainment and also that genes are only one determinant of cognitive ability, then genetically informed designs still do not account fully for cognitive ability as a confound.

According to [10], Social science and genetic science still have fairly little engagement with one another, but the continued swift development of genetic science has certainly gained social scientists' attention. First, some social scientists are incorporating techniques from quantitative and molecular genetics into their work.

Studies shows that Americans develop incorrect ideas about human genetic variation for two possible reasons. First, there is a lot of misinformation about race and genetics in our culture $[25,26]$. This misinformation has been promulgated by individuals who have a racially biased social agenda [25, 26]. Such individuals try to convince other people that racial stereotypes are caused by genetics because they want to mislead people into thinking that racial inequality is natural and therefore not worthy of redress $[18,28]$. People who have been misled may then use stereotypes as a way to make sense of the social world around them, further reinforcing the false idea that racial inequality is genetic [10, 17]. Second possible reason why people tend to believe misleading information about the race is because people live in segregated communities in the United States [5]. As segregation causes social isolation, it prevents people from seeing that individuals in another group are similar to them [4]. It could also prevent them from seeing that they differ from people in their own group in the same way that people in another group differ from each other.

Twenty-five years ago, serious scholars could credibly speculate that genetic differences might prove of only trifling importance for understanding individual differences in psychological characteristics, behaviors, and life attainments [5]. Now, the terrain has shifted to arguments that genetic influence should not be overstated and can only be understood in a context of extensive causal interdependence with the social environment $[25,28]$.

\subsection{Statement of the Problem}

Numerous scholars categorized human being based on color, language, shape of face, size of eye, position of nose and ear, color of hair and eye, type of hair, cognitive competence, and so on. However, this study tried to analyzed critical the social genetics and linguistic inquiry of human being regardless of anything. Therefore, this research is uneque in its approach.

\subsection{Objectives of the Study}

The objectives of the study are as follows:

1. To introduce this complex idea to the biologists and linguists to reduce their racial baises.

2. To make sense of social genetics and sociolinguistics are the major parameter of human race and genetics than hereditary genetics.

\subsection{Methods and Material}

In this study the critical is used as paradigm. Regarding techniques of data analysis. The qualitative approach is utilized. Concerning data collection tools, the secondary data are collected from journals, findings of different researches, books, and proceedings. Therefore, this research is desktop research. 


\section{Data Analysis and Presentations}

The researcher used the concept of proto-world language from proto-language perspective. Let present this concept from sociolinguistics perspective. For instance, language family is a group of languages with a common ancestor. This common ancestor is referred to as a protolanguage. Ancestor in this case is the linguistic features that shared by those languages shared same language family. These has nothing to do with genetic relationship of a group of people spoken these languages. In this case the protolanguages of different families also had ancestors, which must have been members of older language families. Many of the branches of these older families may still exist, but they have separated so much that we are not able any longer to discover the family ties.

More precisely, according to the data obtained from different journal shows that the source of most language of the world are one and same. They were developed from common source. Evidence of a common origin for groups of languages was readily available in Europe, in that French, Spanish, Italian, and other Romance languages were clearly descended from Latin. My argument is not only most but also source all language of the world are the same. The source of human being is one East Africa particularly Ethiopia. It was convincingly examined the hypothesis that there was once a language from which many of the languages of Eurasia have derived. This common ancestor is referred to as a protolanguage. The classification of this languages into different language family are typological classification and genetic classification. These classification contains less than $1 \%$ of differences in language feature. Like $99.9 \%$ of the DNA between any two humans is similar. More that $99 \%$ of the characterisctis and linguitic feature of human language of the world are identical. For instance let lake Afaan Oromoo and Tigrigna languages, regardless of their phylum classification the pulmonic consonants found in Afaan Oromoo is found in Tigrigna except the pharyngeal sound $/ \varsigma /$. In addition all non-pulmonic consonants found in Tigrigna are found in Afaan Oromoo except implosive soung $/ \mathrm{d} /$. Regarding the vowels all are identical in both languages. This classification has nothing to do with the hereditary genetics of a target speech communities.

Besides, Linguists do not agree about the number of language families in the world. Some linguists may be of the opinion that some two language groups are related that is, that they are branches of a single family while others reject the evidence meant to prove the relatedness, concluding that the two groups constitute separate language families.

Is all languages of the world are related? This is a reasonable question to ask. But, how one can prove this? Here it is good to introduce the notion of phone in linguistics. Like an atom is a smallest unit of matter that decomposed into further molecules in chemistry, sound is the smallest unit that can be described further based on place of articulation, maner of articulation and status of glottis. To start with consonanats, basically consonants are devided into two.
Pulmonic and non pulmonic cansonants. The pulmonic cansonanats are produced bt the air come from the lung. Most pulmonic consonants are found in most languages of the world. Therefore, most languages of the world share these consonants in common. The consonants are many in number. Similarly, non-pulmonic consonants are produced above the larynx. These consonants are few in number when compared with that of pulmonic consonants. The nonpulmonic consonants composed of clicks, ejectives and implossives. Some languages of the world shared these consonants in common. Therefore, reconstructiing protoworld languages in all parts of the world

The feature of most vowels of languages of the world are almost the same or nearly the same. The vowels $/ \mathrm{a} /, / \mathrm{e} /, / \mathrm{i} /$, $\mathrm{lo} /$, and $/ \mathrm{u} /$ are the vowels shared by most languages of the world. Therefore, most languages of the world shared the vowels and consonants in common. This can pave the way for monogenesis hypothesis more convinsing than that of a polygenesis hypothesis. In this case almost all languages of the world are from common ancestry.

On the other hand language change is the universal nature of human language of the world. Language change can be exist in different ways. Sometimes the meanings of lexicons, vocabularies and words are changed. In addition, ways of pronunciations of the lexicons, vocabularies, lexemes and words are changed. Moreover, through word formation process new words are adopted, old words are discarded, inflections come and go, in some languages the linguistic structure such as words, phrases, clauses, and sentences are changed. For example the Latin word Brothren became Brother in English, the Ge'ez /k'ätälä/ 'he killed' became /gädälä/ 'he killed' in Amharic, in Latin /habe:re/ 'to have' became /ave:re/ 'he have' in Italain, and /ho:ra/ 'time, hour' in Latin became /o:ra/ 'time, hour in Italian. /okto://ojtu/, /otfo/, /otto/, and /opt/ are eight in Latin, Portuguese, Castilian, Italian, and Romanian respectively. These feature is the among the major characteristics of language of the world.

In human language if sound correspondences can be established regularly between two or more languages, these languages are belong to same language phylum or the languages are genetically related, that is, they belong to the same language family and are descendants of the same protolanguage. It has nothing to do with human hereditary genetics.

In principle the language family tree is conventional. According to [28] a conventional family tree of the Germanic languages and serves as a starting point for a discussion of the family-tree model. It shows that the family concept is recursive. Thus English, Friesian, etc. form a West Germanic family. This, together with the North Germanic family and the single-member East Germanic family, forms the Germanic family. The latter, along with the Romance, BaltoSlavic, Indo-Iranian, and other, some single-member, families, is part of the Indo-European family. Language family tree cannot do justice to the historical relationships between the languages. This shows that language family tree 
is not something related to hereditary genetics of the speakers of the language.

On the other hand the origins of the phylogenetic diversity of languageslie far back beyond know ability. Are all today's language families descended from a single 'Proto World'? Many people have assumed so, not on linguistic evidence but on the basis of a single humanorigin in east Africa. The comparative method allows us to reconstruct linguistic history only as farback as about 8000 years, yet structurally modern language has probably been around for many years [28].

The romance languages spoken in different counties share nearly the same lexicon for the word key. For example, in Franco-Provençal /clâ/, in French /clé/, in Occitan /clau/, in Catalan /clau/, in Spanish /llave/, in Romansch /clav/, in Piedmontese /ciav/, in Romagnol /cêv/, in Italian /chiave/, in Sicilian /chiavi/, in Sardinian /ciae/, in Portuguese /chave/, in Romanian /cheie/, in Aromanian /cljai/, and in Istriot /ciave/. Such feature is common in most language of the world. That is why the researcher argue on the one proto-language ought to be created for the languages spoken as mother of langueas spoken in third planet.

According to [27], the Tutsi appear to share a close genetic kinship with neighboring Bantu populations, particularly the Hutu. However, these people made war againest each other two decades before. The world ought to learn from this. The Tutsis are thought to have originally come from Ethiopia and arrived after the Hutu came from Chad. In this universe at communal level nothing is yours. Everything is ours. Rwanda belong to all human being.

Language is a tool to social contraction not deconstrction. Look at the following language cause for civil war between Hutu and Tulsi:

1. Hutu daughters are more suitable and conscientious in their role as woman, wife and mother of the family. Are they not beautiful, good secretaries and more honest?

2. Every Tutsi is dishonest in business. His only aim is the supremacy of his ethnic group.

3. Hutu should stop having mercy on the Tutsi.

4. Must constantly counteract Tutsi propaganda.

5. Hutu must be firm and vigilant against their common Tutsi enemy.

6. Hutu Ideology, must be taught to every Hutu at every level. Every Hutu must spread this ideology widely.

Source: [27]

If speaking same language is an indecator of same genetic hereditary, Hutu and Tulsi speak same language called Rwanda-rundi. Hutus speak Rwanda-Rundi as their native tongue, which is a member of the Bantu subgroup of the Niger-Congo language family. Rwanda-Rundi is subdivided into the Kinyarwanda and Kirundi dialects, which have been standardized as official languages of Rwanda and Burundi respectively. It is also spoken as a mother tongue by the Tutsi and Twa. Above all humanity and social genetics must given prior.

A new word, steganography, which is the art of hiding information in elecronic text, entered English language with the internet revolution. Verbs like disrespect and download entered the language quite recently, as have nouns like byte and email [24].

According to [24] people start disrespecting each other post internet revolution. Pre internate revolution people are very eager to respect each other. This signals are blinking in Ethiopia. Ethiopia's indigenous culture which pave the way to respect each other for a long period of time seems dematerialize. This is true to most countries of the world. In addition, post internet revolution more lexicons are produced in English.

\section{Conclusion}

In general the finding of the study demonstrate that it is incorrect to think that the speaker of same language and languages of same phylum are from the same race and genetically uniform. On other word language is not the only gurranty for genetically relatedness. Instead, being human by itself is the only common characterisct of people of the world.

The pioneer objective of language is communication. English means not UK or British. Rather it is just a language spoken in different part of the world. That is why Nigeria adopted English as an official language. German is a language spoken in coutries like Germany, Australia and so forth. The same is true to French. Therefore, it better to think things from this perspective in order to create harmoney and positive thinking among people of the world and target speech communities. Especially, in Africa and Asia language should not be a means of ethnic conflict. This might resulted to the future of Africa and Asia will be brighter that darker.

The concept of hereditary genetics distinguish an individual or a group of individual from the other is a refutational way that triggers a misconception, and incorrect. The world outlook, and paradigm of the target speech community or an individual is not a consequence of hereditary genetics, rather this can be considered as an misconception of genetics.

Scientists do not agree about whether race is biologically real. $99.9 \%$ of the DNA between any two humans is identical. When genetics look at the variation portion of human DNA $(0.1 \%)$ they find:

1. $95.7 \%$ of differences are between people of the same race,

2. $4.3 \%$ of differences are between peoples of different races.

Skin color changes continuously as one moves away from the equator. But there is more variation in skin color across race than within races. Let adapt this concept to linguistics. A group of people born by chance in the same or nearly the same geographical location might share same language as a vernacular language. These speech communities are different from other target community speak another language. More explicitly $99.9 \%$ of the DNA between these two different speech communities are exactly the same. As mentioned above not only $99.9 \%$ of the DNA of two human is identical. 
But also, more than $99 \%$ of language of the world share same consonants and vowels. The phoneme chart of most language of the world is almost the same. Therefore, ethnic conflict in different prt of the world particularly Africa and Asia has no theoretical and practical reasosns. In another word ethnic conflict among two races has no reaosn and a conflict between groups those share $99.9 \%$ of the DNA and $99 \%$ of the linguitic characteristics.

Regarding identity there are two type of identity: permanent and temporary identity. Permanent contains family, and a group of people live in the same or nearly the same area share same assets. Whereas, temporary identity composed of power, money and minor affairs faces in day to day activity. To create harmoney among the target speech community, the priority ought to given to the permanent than temporary. It is true that in a certain social context if natural disaster happen regardless of language, religion, "ethnic" background it will harm all equally. Climate change, El-nino, flood, fire, sunami, happened to all equally and equally. Therefore, social context is among criteria for social genetics.

Currently, in developed countries such as US and Europe "natives" are standing againest "non-natives". Such thinking ought to stop and come to an end. To answer the question whom America belong? Red Indian? or Mexicans? or African? It is better to look at things from social genetics and sociolinguitics. Now a day dwellers of USA share the same language and social values. This does not mean that, those doesn't share same language with them but live in US is genetically unlike. If some incident happen to USA, all share equaly.

Since the source of human being is East Africa particularly Ethiopia, the concept of languages are from same mother source ought ro be introduced to the world. Because the issue of racism is a potential threat to the world including USA and Europe. If it is not managed well cause orimmediate cause for world war III. Different speech community ought to make sense of withingroup variation if they are to understand between group variation. Because, these two "different" speech communities are genetically, linguistically and genomically a like and share similar sets of within-group differences.

\section{References}

[1] Andreychik, M. R., \& Gill, M. J.. Do natural kind beliefs about social groups contribute to prejudice? Distinguishingbio-somatic essentialism from bio-behavioral essentialism, and both of these from entitativity. Group Processes \&Intergroup Relations, (2014) 18 (4), 454-474.

[2] Crawford, N. G., Kelly, D. E., Hansen, M. E. B., Beltrame, M. H., Fan, S., Bowman, S. L.,...Tishkoff, S. A.. Loci associated withskin pigmentation identified in African populations. $\begin{array}{lllll}\text { Science, } & 358 & \text { (6365), } & \text { (2017) } & 1-25 .\end{array}$ https://doi.org/10.1126/science.aan8433

[3] Dar-Nimrod, I., \& Heine, S. J.. Genetic essentialism: On the deceptive determinism of DNA. Psychological Bulletin, 137 (5), (2011), 800-818. https://doi.org/10.1037/a0021860

[4] Donovan, B. M. Putting humanity back into the teaching of human biology. Studies in History and Philosophy of Science
Part C: Studies in History and Philosophy of Biological and Biomedical Sciences, 52 (2015a), 65-75. https://doi.org/10.1016/j.shpsc.2015.01.011

[5] Donovan, B. M.. Reclaiming race as a topic of the U.S. biology textbook curriculum. Science Education, 99 (6), (2015b) 1092-1117. https://doi.org/10.1002/sce.21173

[6] Doron, C.-O.. Race and genealogy: Buffon and the formation of the concept of "race". E. Casetta \& V. Tripodi, MakingSense of Gender, Sex, Race, and the Family, Humana. Mente Journal of Philosophical Studies, 22, (2012) 75-109.

[7] Donovan B. M Toward a more humane genetics education: Learning about the social and quantitativecomplexities of human genetic variation research could reduce racial bias in adolescentand adult populations. Science EducationPublished by Wiley Periodicals, 2019 Inc. wileyonlinelibrary.com/journal/sce.

[8] Foster, M. W. Looking for race in all the wrong places: Analyzing the lack of productivity in the ongoing debate about race and genetics. Human Genetics, 126 (3), (2009). 355-362. https://doi.org/10.1007/s00439-009-0674-1

[9] Hudson, N.. From "nation" to "race": The origin of racial classification in eighteenth-century thought. EighteenthCentury Studies, 29 (3), (1996) 247-264.

[10] Freese J. and Shostak S. "Genetics and Social Inquiry" ANRIV 2009.

[11] Jackson, J. P., Jr., \& Depew, D. J. Darwinism, democracy, and race: American Anthropology and evolutionary biology in the twentieth century. (2017) New York, NY: Routledge.

[12] Keller, M. C.. Gene×environment interaction studies have not properly controlled for potential confounders: The problem and the (simple) solution. Biological Psychiatry, 75 (1), (2014) 18-24. https://doi.org/10.1016/j.biopsych.2013.09.006

[13] Kimel, S. Y., Huesmann, R., Kunst, J. R., \& Halperin, E. Living in a genetic world how learning about interethnicgenetic similarities and differences affects peace and conflict. Personality and Social Psychology Bulletin, 42 (5), (2016). 688-700.

[14] Kaplan, J. M., \& Winther, R. G.. Prisoners of abstraction? The theory and measure of genetic variation, and the very concept of "race". Biological Theory, 7 (4), (2013a) 401-412.

[15] Kaplan, J. M., \& Winther, R. G.. Realism, antirealism, and conventionalism about "race". (2013b) Retrieved from http://philpapers.org/rec/KAPRAA

[16] Mallon, R.. Was Race thinking invented in the modern West? Studies in History and Philosophy of Science Part A, 44 (1), (2013) 77-88. https://doi.org/10.1016/j.shpsa.2012.10.001

[17] McWhorter J. et al Language families of the world. Virginia: colombia university press. 2019.

[18] Morning, A. Toward a sociology of racial conceptualization for the 21st century. Social Forces, 87 (3), (2009) 1167-1192.

[19] Morning, A. J. The nature of race: How Scientists think and teach about human difference. Berkeley, CA: University of California Press. (2011).

[20] Samuel L., and Wolde E., 'Linguistic Analysis of Moribund Lexicons: Focus on Baalee Oromo', Journal of Science and sustainable Development (JSSD), VOLUME 2 ISSUE 1, (2015) 73-85. 
[21] Samuel L., and Wolde E., 'Critical Analysis of the Diacritic /'/ inAfan Oromo', Ethiopian Journal of Social and Language Studies, (2017) Vol. 4 No. 1.

[22] Samuel L. Assesment of mother toungue education at primary schools: West Shoa in focus (unpublished research). (2019).

[23] Soylu, Y. N., Estrada-Villalta, S., \& Adams, G. The (biological or cultural) essence of essentialism: Implications forpolicy support among dominant and subordinated groups. Frontiers in Psychology, (2017) 8, 900. https://doi.org/10.3389/fpsyg.2017.00900

[24] Victoria F. Introduction to Language 2003.

[25] Williams, M. J., \& Eberhardt, J. L.. Biological conceptions of race and the motivation to cross racial boundaries. Journal of Personality and Social Psychology, 94 (6), (2008) 1033-1047.
[26] Willinsky, J. Learning to divide the world: Education at empire's end. Minneapolis, MN: University of Minnesota Press (1998).

[27] https://www.avila.edu/_userfiles/Education/FulbrightHays\%20Project/Educator\%20Microsite/Curriculum\%20Unit/ Hillstock/Rwanda_Genocide_The_Impact_of_pdf

[28] https://en.wikipedia.org/wiki/Hutu\#Language

[29] https://en.wikipedia.org/wiki/Origins_of_Hutu,_Tutsi_and_Tw a

[30] https://en.wikipedia.org/wiki/Tutsi

[31] https://www.thoughtco.com/location-of-conflict-tutsis-andhutus-3554918 